\title{
The criminal liability of the medical team considering the recent orientation of the Italian Court of Cassation
}

\author{
Emanuela Furramani, PhD \\ University "Tor Vergata", Rome, Italy \\ University “Luigj Gurakuqi”, Shkodër, Albania \\ Rrezart Bushati, PhD \\ University "Tor Vergata", Rome, Italy
}

\section{Abstract}

This article aims to analyze the thematic of medical team liability considering the recent Italian Supreme Court case-law, highlighting the various problems linked to the identification of the responsibility of each member of the team. The participation of several subjects in the execution of medical treatment makes the question of criminal liability very complex, especially when it comes to inauspicious events, such as injuries or death, occurring during medical treatment. The question concerns the exact identification of the duty of care and vigilance of the medical team and whether this duty is in line with the principle of individual criminal responsibility guaranteed by Article 27 of the Italian Constitution.

In this regard, the case-law has elaborated the so-called "principle of reasonable confidence", according to which the division of labour that belongs to each member should involve a delimitation of his responsibility, limited only to what is within his competence, except in case of the person who organizes, directs, and controls the team. Precisely, based on this principle, the Italian Supreme Court in 2018 reasserted that in the medical team is necessary to identify the role played by each member, thus avoiding resorting to objective responsibility.

Keywords: medical team; medical liability; the principle of reasonable confidence; the principle of individual criminal responsibility.

\section{Introduction}

The Italian doctrine and case-law consider the medical team as the participation and collaboration of several health care professionals with different specializations in the execution of a specific medical health treatment, which interact with each other by operating at the same time (synchronous) or at different times (diachronic) ${ }^{1}$. The participation of several physicians in a medical team in the execution of surgical

\footnotetext{
${ }^{1}$ See Cass. Pen., Sez. IV, 3 novembre 2011, n. 46961.; Cass. Pen., Sez. IV, 23 gennaio 2017-18 maggio 2018, n. 22007.
} 
treatments makes it difficult to identify the criminal liability of each of the members for unfortunate events, such as injury or death, occurring during the medical treatment ${ }^{2}$.

\section{The principle of reasonable confidence, according to the Italian Court of Cassation}

The questions on this issue relate to the exact identification of the duty of diligence and vigilance of each member of the medical team and whether this duty is in line with the principle of individual responsibility that characterizes the criminal law, according to Article 27, the first paragraph of the Italian Constitution.

In this sense, the adoption of the criteria of predictability and avoidance of the event as the key criteria of any culpable liability, are considered not sufficient to attribute the event to the members of the medical team ${ }^{3}$. As a matter of fact, in addition to the above requirements, it is necessary to also consider the peculiar nature of the medical activity. Thus, to determine and individualise the criminal liability of subjects who collaborate for a single result ${ }^{4}$, it is essential to identify other criteria.

About this issue, the recent doctrine and case-law have developed basic criteria to be taken into consideration to identify the medical liability. One of these principles is the

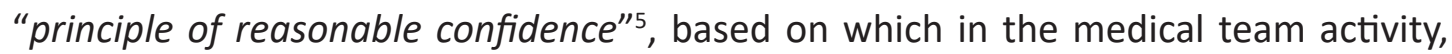
each of members is bound to follow the precautionary rules of his competence or specialization and confide in the fact that the other members will behave in the same way respecting the precautionary rules of their activity 6 . In this way, the principle of reasonable confidence delimits the amount of diligence of each doctor part of the team on the work of other healthcare professionals ${ }^{7}$.

In this sense, the Court of Cassation in the decision of 19 January 2018, no. 2354, re-affirmed that the principle of reasonable confidence can be applied: "in every situation in which a plurality of subjects finds themselves operating to protect the

\footnotetext{
${ }^{2}$ Ambrosetti, F. "La responsabilità penale dell'équipe". La responsabilità medica, Tedeschini, N. Wolters Kluwer Italia S.r.l., Milano, 2016, p. 508.; Malavenda, A. F. "L'équipe medica”. La responsabilità medica, Tedeschini, N. Wolters Kluwer Italia S.r.I., Milano, 2016, pp. 766-770.

${ }^{3}$ App. Bari, 26 gennaio 1981. Foro it., 1983, II-V, p. 167, con nota di Belfiore, E.

${ }^{4}$ Cass. Pen., Sez. IV, 23 gennaio 2017-18 maggio 2018, n. 22007.

${ }^{5}$ See Cass. Pen., Sez. IV, 18 maggio 2018, n. 22007.; Cass. Pen., Sez. IV, 28 maggio 2008, n. 24360, Rago e altri. Giur. it., 2009, 4, p. 948.; Pret. Bologna, 31 maggio 1996, Martinelli ed al. Riv. it. dir. proc. pen., 1997, p. 1043.; Cass. Pen., 20 marzo 1991. Cass. pen., 1992, p. 2754.; Mantovani, M. "La responsabilità penale nell'attività medico-chirurgica in équipe fra teoria e prassi”. Nuova giur. civ. comm., 2010, p. 1169.; Ambrosetti, F. “La responsabilità", cit., p. 508.; Di Pentima, M. G. La responsabilità per l'attività sanitaria in équipe, Giappichelli Editore, Torino, 2009, p. 153.; Malavenda, A. F. “L'équipe medica”, cit., p. 766.; Risicato, L. L'attività medica di equipe tra affidamento ed obblighi di controllo reciproco, Giappichielli Editore, Milano, 2013, p. 40.; Fortunato, G. "Ancora sul principio di affidamento e l'équipe medica". Dir. Pen. Cont., 2017, 5, p. 31.

${ }^{6}$ Lanza, E. "La responsabilità penale del medico negli orientamenti della dottrina e della giurisprudenza". La responsabilità in ambito sanitario, Aleo, S., De Matteis, R., Vecchio, G., II, Padova, 2014, p. 701.

${ }^{7}$ Mantovani, F. "Il principio di affidamento nel diritto penale". Riv. it. dir. e proc. pen., 02, p. 536.; Mantovani, F. Diritto penale, Padova, 2007, p. 174.; Terrizzi, A. L. "Linee guida e saperi scientifici "interferrenti”, la Cassazione continua a non applicare la legge Gelli-Bianco". Dir. pen. cont., 2018, n. 7, p. 104.
} 
same legal asset based on specific duties divided between them. (...) Thus configured, the principle of reasonable confidence serves as a limit to the obligation of diligence imposed on each holder of the guarantee position" ${ }^{\prime}$.

Considering this principle, the division of labour incumbent on each of the doctors should entail a delimitation of his responsibility, limited only to what is within his competence ${ }^{9}$, except for the person who organizes, directs, and controls the medical team. Otherwise, we had to admit the doctor's criminal liability also for the work of others, when the conduct or omission does not fall within his area of competence, in violation of the principle of individual criminal responsibility guaranteed by Article 27 , paragraph 1, of the Italian Constitution ${ }^{10}$.

Well, for this reason, the recent case-law considers the principle of reasonable confidence an acceptable choice which is part of the living law ${ }^{11}$, also because, as we can see, the delimitation of the responsibility of each of the participants of the medical team, within the limits of their specific tasks, is in line with the principle of individual criminal responsibility: "under which each member is liable for the consequences of his conduct, whether actions or omissions and within the scope of his knowledge and specialization, while it is not liable, however, for any violation of the precautionary rules by others"12.

The Italian Court of Cassation re-affirmed the position above mentioned, observing that the principle of reasonable confidence represents a safety factor since each of the members of the team is left free to carry out his work based on his specific specialization by following the rules of diligence, prudence and expertise required. But on the other side, the Court recognizes that it also represents a risk factor, since the medical team activity needs the collaboration and coordination of each of the members who have "shared obligations" to a single result ${ }^{13}$.

In the same way the Italian Supreme Court in the decision of May 31, 2017, no. 27314, considering the foregoing, states the need for a balance between the principle of selfresponsibility and the principle of reasonable confidence ${ }^{14}$. On the one hand, every

\footnotetext{
${ }^{8}$ Cass. Sez. IV, 19 gennaio 2018, 2345: https://renatodisa.com/corte-cassazione-sezione-quarta-penale-sentenza-19-gennaio2018-n-2354-nelle-ipotesi-trattamenti-sanitari-affidati-ad-pluralita-medici/.

${ }^{9}$ See Cass., 13 giugno 1996. Foro it., 1997, II, p. 417.; Cass., 15 luglio 1991. Giust. pen., 1992, II, p. 223.; Vallini, A. “Cooperazione e concause in ipotesi di trattamento sanitario "diacronicamente plurisoggettivo". Dir. pen. proc., 2001, p. 480.

${ }^{10}$ See Ambrosetti, F. La responsabilità penale, cit., p. 513.; Cass. Pen., Sez. IV, 19 gennaio 2018, n. 2354.

${ }^{11}$ Cass. Pen., 19 luglio - 4 settembre 2018, n. 39733.; Cass. Pen., 23 gennaio 2017-18 maggio 2018, n. 22007.; Cass. Pen., 19 gennaio 2018, n. 2354.; Cass. Pen., 31 maggio 2017, n. 27314.; Cass. Pen., Sez. IV, 3 novembre 2011, n. 46961.

${ }^{12}$ Cass. Pen., Sez. IV, 28 maggio 2008, n. 24360, cit.; Cass. Pen., 22 maggio 2009, n. 32191.; Cass., sez. IV, 21 maggio 2017 , n. 27314.; Cass. Pen., 18 dicembre 2009, dep. 26 gennaio 2010, n. 3365.; Cass. Pen., 18 dicembre 2009, dep. 26 gennaio 2010, n. 3365.; Marinucci, G. and Marrubini, G. "Profili penalistici del lavoro medico - chirurgico in équipe”. Temi, 1968, p. 217.; Belfiore, E. “Sulla responsabilità colposa nell'ambito dell'attività medico - chirurgica in équipe”. Foro it., 1983, II-V, p. 167.

${ }^{13}$ Cass. Pen., Sez. IV, 11 ottobre 2007, n. 41317. Ragiusan, 2008, pp. 287-288 and: http:/dejure.giuffre.it.

${ }^{14}$ Cass. Pen., Sez. IV, n. 27314, 31 maggio 2017: http://www.anaao.it/public/aaa_9434656_casspen_27314_2017.pdf.
} 
doctor part of the team is free to carry out his duties, relying on the respect of the medical rules (leges artis) by the other members of the team and on the other, each member must supervise the work of others, where the skills allow it ${ }^{15}$. Therefore, in the opinion of the Court, the obligation to supervise the others' actions must not be transformed into "a sort of generalized obligation", risking to "invade the areas of competence of others". ${ }^{16}$

For this reason, the medical activity carried out by a team is considered a collaboration of several specialists, on an equal basis, where each member must entrust in the diligent and correct behaviour of his colleagues ${ }^{17}$. However, it is essential to emphasize that: in this group activity, generic diligence must not fail, especially when there are subjective and objective circumstances that indicate doubts on the conduct of the work diligently and correctly by the colleagues ${ }^{18}$. According to a part of the doctrine, the concepts of predictability and avoidance of the event are concepts that integrate the principle of reasonable confidence ${ }^{19}$. It also stated that each doctor part of a team is bound to observe the rules related to his area of competence, thus perform his duties correctly, in a qualified and responsible manner. This is a primary obligation of each member of the medical team. Instead, the obligation to control the work of others represents a secondary and eventual obligation, that depends on the tasks that each of the team members occupies within the group ${ }^{20}$.

In this regard, the Italian Court of Cassation, in the decision of 19 January 2018, no. 2354, reaffirms the previous case-law orientation on the principle of reasonable confidence. The Court states that to identify the criminal liability of the doctor, part of the medical team due to the unfortunate outcome of the intervention, it is necessary to carry out a careful analysis of the duties of each of the components and the contribution of each of them to the occurrence of the harmful event. In such a way as to exclude the $a$ priori liability of the entire medical team and consequently the objective liability of the same ${ }^{21}$.

In this sense, healthcare professionals are required to carry out their activities according to the canons of medical science, protocols and guidelines as provided for

\footnotetext{
${ }^{15}$ Ambosetti, F. La responsabilità penale, cit., p. 508.

${ }^{16}$ See Cass. Pen., Sez. IV, 31 maggio 2017, n. 27314.; In the same direction Cass. Pen., Sez. IV, 30 marzo 2016, n. 18780.

${ }^{17}$ Cfr. Risicato, L. “Omesso controllo sul malgoverno di macchinari capricciosi: non c'è responsabilità penale del dirigente medico”. Giur. it., giugno 2016, p. 1490.

${ }^{18}$ Bilancetti, M. and Bilancetti, F. La responsabilità penale e civile del medico, Cedam, Padova, 2013, p. 881.; Cass. Pen., 18maggio 2018, n. 22007, cit.

19 Ibid.; Di Pentima, M. G. La responsabilità cit., p. 157.

${ }^{20}$ In this sense Risicato, L. L'attività medica, cit., pp. 42-43.; Roiati, A. Medicina difensiva e colpa professionale medica in diritto penale, Milano, 2012, p. 257.; Mantovani, M. Il principio di affidamento nella teoria del reato colposo, Giuffre Editore, Milano, 1997, p. 155.; Belfiore, E. Sulla responsabilità colposa, cit., p. 168.

${ }^{21}$ Cass. Pen., Sez. IV, 19 gennaio 2018, n. 2354.
} 
by the Gelli-Bianco Law no. 24/17, which introduced in the Italian Criminal Code the article 590 sexies, reforming the liability of the health care workers ${ }^{22}$.

An important objection - among many - to the Gelli - Bianco Law concerns the second paragraph of art. 590 sexies, which provides for the exclusion of medical liability due to inexperience of the doctor who acts in compliance with best practices and guidelines published by law $w^{23}$ or in any case accredited by the scientific community, except in cases where the situation of the patient requires a different behaviour. It is necessary to note that the Gelli-Bianco Law presents the same perplexities that also concern the Balduzzi Law ${ }^{24}$. The doctrine notes in this sense the risk that the guidelines or best medical practices recognized and published under the law, from "simple recommendations become legal prescriptions" 25 , and may hide, or justify the negligent behaviour of doctors ${ }^{26}$. On the other hand, the Italian Supreme Court caselaw has affirmed constantly that the cases in which the guidelines are considered binding precautionary rules for the doctor are rare, due to the difficulty of standardizing medical activity, bearing in mind the scientific evolution and existence of alternative therapies characterized by the same scientific foundation ${ }^{27}$.

\footnotetext{
${ }^{22} \mathrm{Cfr}$. Romano, B. "La responsabilità penale dell'esercente la professione sanitaria, tra antichi dubbi e nuovi problemi". Dir. pen. cont., 16 novembre 2018: https://archiviodpc.dirittopenaleuomo.org/upload/8372-romano2018a.pdf.; Cass. Sez. IV, 20 aprile 2017, n. 28187, Tarabori.; Cupelli, C. "La legge Gelli-Bianco e il primo vaglio della Cassazione: linee guida sì, ma con giudizio". Dir. pen. cont., n. 6, 2018, p. 280.; Piras, P. "Il discreto invito della giurisprudenza a fare noi la riforma della colpa medica”. Dir. pen. Cont., 4 luglio 2017: https://archiviodpc.dirittopenaleuomo.org/upload/PIRAS_2017b.pdf.; Caletti, G. M. and Matheudakis, M. L. "La Cassazione e il grado della colpa penale del sanitario dopo la riforma "Gelli - Bianco". Dir. proc. pen., 2017, p. 1396.

${ }^{23}$ See Mattheudakis, M. L. "La punibilità della colpa penale relazionale del sanitario dopo la riforma "Gelli-Bianco". Dir. pen. cont., 4, 2019, pp. 65-80: https://dpc-rivista-trimestrale.criminaljusticenetwork.eu/pdf/DPC_Riv_Trim_4_2019_Mattheudakis. pdf.; Caletti, G. M. "Il percorso di depenalizzazione dell'errore medico". Dir. pen. cont., 4, 2019, pp. 15-16: https://dpc-rivistatrimestrale.criminaljusticenetwork.eu/pdf/DPC_Riv_Trim_4_2019_Caletti.pdf.; Cfr. Cupelli, C. "La responsabilita penale degli operatori sanitari e le incerte novita della legge Gelli-Bianco". Cass. Pen., 2017, pp. 1765-1970.

${ }^{24}$ Caletti, G. M. "Il percorso di depenalizzazione dell'errore medico". cit., pp. 7-8, 12-15.; Blaiotta, R. "Niente resurrezioni, per favore. A proposito di S.U. Mariotti in tema di responsabilità medica". Dir. pen. cont., 28 maggio 2018: https://archiviodpc. dirittopenaleuomo.org/upload/2125-blaiotta2018a.pdf.; Civello, C. "Responsabilità medica e rispetto delle "linee guida" tra colpa grave e colpa lieve (la nuova disposizione del decreto sanità)". Arch. pen., 2013, n. 1.; De Francesco, G. "Al capezzale della colpa medica". Riv. it. med. leg., 2015, 3, pp. 884-889.

${ }^{25}$ Ibid, p. 3.; Brusco, C. "Cassazione e responsabilità penale del medico. Tipicità e determinatezza nel nuovo art. 590 sexies c.p." Dir. pen. cont., 11, 2017, pp. 211-219: https://archiviodpc.dirittopenaleuomo.org/upload/6599-brusco1117.pdf.; Di Landro, A. R. Dalle linee guida e dai protocolli all'individuazione della colpa penale nel settore sanitario, Giappichelli Editore, Torino, 2012, pp. 310-320.

${ }^{26}$ Guerriero, C. Il disegno di legge Gelli cambia i connotati della responsabilità medica, 16 febbraio 2016: www.iurisprudentia.it.

${ }^{27}$ Caletti, G. M. “Il percorso di depenalizzazione dell'errore medico", cit., pp. 8-11.; Campana, T. “La correlazione tra inosservanza e/o applicazione delle "linee guida" e responsabilità penale del medico". Cass. pen., 2012, p. 550.; Palazzo, F. "Responsabilità medica, "disagio» professionale e riforme penali". Dir. pen. proc., 2009, 9, pp. 1063-1066.; Di Giovine, O. "La responsabilità penale del medico: dalle regole ai casi". Riv. it. med. leg., 2013, I, pp. 61-66.
} 


\section{The limits imposed on the principle of reasonable confidence}

The principle of reasonable confidence, despite being considered a guiding criterion in the medical team activity, encounters some specific limits ${ }^{28}$. In the first place, it does not operate against the person who is at fault, for the violation of the precautionary rules or the omission of the necessary conduct ${ }^{29}$. Furthermore, the full application of the principle of reasonable confidence, as the Court of Cassation also underlined: "could entail the risk that each doctor part of the team could be completely disinterested in the work of others, and this could lead to defects in cooperation between doctors "30.

Another limit to the principle of reasonable confidence is the "basic choice" relevant for the intervention, a choice that is shared by all doctors' part of the team. Moreover, if this choice is wrong or guilty, all the doctors who make up the team are to be held responsible ${ }^{31}$.

The last limit placed on the application of the principle of reasonable confidence concerns the subject who is in a special position in the hierarchy, such as the head of the medical team, who organizes, controls, and supervises the other collaborators. In this context, the head of the team holds the position of guarantee for the protection of the patient's health ${ }^{32}$; consequently, he has the legal obligation to control and supervise the work of the other components ${ }^{33}$.

Regarding the medical team liability, the Italian Supreme Court case-law has developed another guiding criterion the so-called "evident error". According to this criterion, every doctor is responsible not only for the compliance with the rules of diligence and expertise related to his specific tasks, but he must also know and evaluate the activities carried out by colleagues, to remedy the errors made by them if they are

\footnotetext{
${ }^{28}$ Regarding the principle of reasonable confidence see: Buzzoni, A. "Responsabilità medica in équipe: gli orientamenti giurisprudenziali", 16 settembre 2006, p. 2: https://www.altalex.com/documents/news/2006/10/11/responsabilita-medica-inequipe-gli-orientamenti-giurisprudenziali.

${ }^{29}$ Cass. Pen., 18 dicembre 2009 dep. 26 gennaio 2010, n. 3365: “il principio di affidamento non è, però, invocabile sempre e comunque (...). Non è certamente invocabile, infatti, allorché l'altrui condotta colposa si innesti sull'inosservanza di una regola precauzionale proprio da chi invoca il principio: ossia allorché l'altrui condotta colposa abbia la sua causa proprio nel non rispetto di norme cautelari, o specifiche o comuni, da parte di chi vorrebbe che quel principio operasse".; Cass. Pen., Sez. IV, 28 maggio 2008, n. 24360.; Cass. Pen., 18 maggio 2005, n. 18568.

${ }^{30}$ Cass. Pen., Sez. IV, 19 gennaio 2018, n. 2354.

${ }^{31}$ Cass. Pen., Sez. IV, 3 novembre 2011, n. 46961. Pers. e danno, 24 gennaio 2012.; Article 14, Codice di Deontologia Medica, 2014: "la rilevazione, la segnalazione e la valutazione di eventi sentinella, errori, quasi - errori, ed aventi avversi valutando le cause e garantendo la natura riservata e confidenziale delle informazioni raccolte".; Cfr. Cass. Pen., Sez. IV, 21 gennaio 2016 ud. 3 dicembre 2015, n. 2541. Giur. it., giugno 2016, p. 1490, con nota di Risicato L.

32 Cass. Pen., Sez. IV, n. 32871/2020.; Cass. Pen., Sez. IV, 6 marzo 2012, n. 17222. Danno e resp., 2012, 7, p. 805.; Cass. Pen., Sez. IV, 12 febbraio 2010, n. 20584, T.G. e altro. Guida al dir., 2010, p. 92.; Malavenda, A. F. "L'équipe medica", cit., p. 767.

${ }^{33}$ Cass. Pen., Sez. IV, 3 novembre 2011, n. 46961.; Cass., sez. IV, 26 ottobre 2011, n. 46824. CED Cass., rv. 252140.; Cass., 29 novembre 2010, n. 24144.; Cass., 2 dicembre 2008, n. 1866. Riv. it. med. leg., 2009, p. 1117.; Cass. Pen., Sez. IV, $1^{\circ}$ dicembre 2004, n. 9739.; Belfiore, E. "Profili penali dell'attività medico - chirurgica in équipe”. Arch. pen., 1986, pp. 298-295.; Di Pentima, M. G. La responsabilità. cit., pp. 131-139.; Ambrosetti, F., Piccinelli, M., Piccinelli, R., La responsabilità nel lavoro medico d'équipe, Utet, Torino, 2003, pp. 102-130.; Di Pentima, M. G. La responsabilità. cit., pp. 118-120.
} 
obvious errors to a reasonably prudent professional. This orientation was recently reaffirmed by the Court of Cassation with the decision of 18 May 2018, no. 22007, where: "In terms of medical liability, the team must be considered as a single and compact entity and not as a community of professionals, in which each one is limited to carrying out his duties. It follows that the duty of care which is attributable to each component of the medical team concerns not only the specific tasks assigned to him but also the control over the work and the errors of others that are evident and not sectoral, as such perceptible with the help of the common knowledge of a reasonably prudent professional." ${ }^{\prime \prime}$

It is therefore evident that the members of a medical team who cooperate in medicalsurgical activity, even if in different sectors, are required to observe the obligations arising from the convergence of all activities towards the common goal which is to safeguard patient health. Accordingly, the members of the team, even if they do not have the specific knowledge of a certain sector of the colleague, can remedy the so-called "evident errors", which are perceptible with the necessary diligence and experience of a reasonably prudent professional ${ }^{35}$. In this direction, the Court of Cassation in 2006 asserted that: "the team member is liable not only for the fact he directly caused but also for the fact committed by another member if he had the concrete possibility to supervise the work and prevent his mistakes" ${ }^{36}$. The procedure is different if the errors are related to specific sectoral knowledge, which are considered not evident, and therefore, not perceptible with the knowledge of a reasonably prudent professional ${ }^{37}$. The most frequent cases in terms of medical team liability are the forgetfulness of foreign bodies in the patient's abdomen, such as gauze or irons. In this regard, the Italian Supreme Court has ruled that the obligation to remove the irons belongs to the entire operating team since all the doctors who are part of the team are responsible for the success of the operation. This obligation cannot be delegated to nurses or paramedics since the latter has only the task of assistance and not of verification ${ }^{38}$.

\section{Reflections on the configuration of Article 113 Italian Criminal Code}

The application of Article 113 of the Italian Criminal Code in case of surgery performed by a team, is a very discussed topic in doctrine ${ }^{39}$. However, the doctrinal orientations

\footnotetext{
${ }^{34}$ Cass. Pen., Sez. IV, 18 maggio 2018, n. 22007: https://www.lexopera.it/wp-content/uploads/2018/05/cass-22007-2018.pdf.; Cass. Pen., Sez. IV, 30 marzo 2016, n. 18780; Cass. Sez. III, $1^{\circ}$ febbraio 2011, n. 2334. Pers. e danno, 22 aprile 2011.; Cass. Pen., Sez. IV, 12 luglio 2006, n. 33619.; Di Pentima, M. G. La responsabilità. cit., pp. 155-163.

${ }^{35}$ Cass. Pen., Sez. IV, n. 53315, 18 ottobre 2016.; Cass. Pen., n. 22007, 18 maggio 2018.; Cass., Sez. IV, 24 gennaio 2005 , n. 18548.

${ }^{36}$ Cass. Pen., Sez. IV, 12 luglio 2006, n. 33619.

${ }^{37}$ Cass. Pen., Sez. IV, 22 maggio 2009, n. 32191. Guida al dir., 2009, p. 94.; Cass. Pen., 18 dicembre 2009, dep. 26 gennaio 2010, n. 3365.

${ }^{38}$ Cass. Pen., Sez. IV, 26 maggio 2004, n. 39062, P.S. e altro. Dir. pen. proc., 2005, p. 27; Cass. Pen., Sez. IV, 6 aprile 2005, n. 22579, Malinconico e altro. Riv. pen., 2006, 7-8, p. 877.

${ }^{39}$ Cfr. Belfiore, E. Profili penali, cit., pp. 266-270.; Id., Sulla responsabilità colposa, cit., pp. 169-170.
} 
and even the Supreme Court case-law do not offer a univocal solution. A part of the most authoritative doctrine considers co-offending in crime under article 113 of the Italian Criminal Code $^{40}$.

It will be interesting to see whether the activity of the doctor who does not supervise the conduct of others can be defined indirectly or atypically negligent according to Article 113 of the Italian Criminal Code ${ }^{41}$. Therefore, is this approach in line with the principle of individual criminal responsibility under Article 27 of the Italian Constitution?

The answer to this question comes from the Supreme Court case-law, which seems to exclude the application of Article 113 of the Italian Criminal Code concerning medical team activities. In this context, the Court of Cassation recognizes that negligent cooffending occurs when several people carry out "an autonomous conduct, in the mutual awareness of contributing, with the conduct or omission of others, to the production of the unwanted event" ${ }^{\prime 2}$, but still predictable. It is therefore considered essential that each culpable conduct is directly connected to the risk of the damaging event, representing an unequivocal causal antecedent ${ }^{43}$.

A better approach to the question of medical team liability for negligent co-offending is offered by the doctrinal elaboration and Italian Supreme Court case-law, according to which negligent actions are involved when:

- The negligent act is the result of several parties who acted independently of each other ${ }^{44}$.

- The event is the result of the conscious and negligent conduct of several people ${ }^{45}$.

In the first case, it is not necessary for the participants being aware that the event may result from their joint action. According to the doctrine ${ }^{46}$, in this hypothesis, the responsibility of each participant is identified based on the general principle of factual causation. In the second hypothesis, however, the conduct of each competitor must be marked by the violation of a precautionary rule and by interacting in a coordinated

\footnotetext{
${ }^{40}$ Bilancetti, M. and Bilancetti, F. La responsabilità penale cit., pp. 863-880.

${ }^{41}$ Cognetta, G. "La cooperazione nel delitto colposo". Riv. it. dir. proc. pen., 1980, p. 63.; Risicato, L. L'attività medica di equipe, cit., p. 19.; Cass., 7 aprile 2004, n. 25311.

${ }^{42}$ Cass. pen., sez. IV, 12 febbraio 2013, n. 16978, Porcu.

${ }^{43}$ Di Landro, A. R. Dalle linee guida, cit., p. 310.; Cfr. Di Pentima, M. G. La responsabilità. cit., pp. 196-200.; Cass. pen., sez. IV, 10 dicembre 2009, n. 6215, Pappadà e altri.

${ }^{44}$ In this sense Cass. Sez. IV, 4 ottobre 2012, n.11439. CED Cass. rv. 255419.

${ }^{45}$ Bettiol, G. "Sul concorso di più persone nei delitti colposi". Scritti giuridici, I, Padova, 1966, p. 18.; Pagliaro, A. Principi di diritto penale, Milano, 2000, pp. 545-550.; Latagliata, V. voce “Cooperazione nel delitto colposo". Enc. del Dir., Ed X, 1962, p. 615.; Di Pentima, M. G. La responsabilità. cit., p. 194.; Bilancetti, M. and Bilancetti, F. La responsabilità penale cit., pp. 863-880.; See Cass. Sez. III, 9 gennaio 2009, n.15707, Abbaneo. Cass. Pen. 2010, p. 626.

${ }^{46}$ Padovani, T. Codice penale, Milano, 2005, p. 615.; Di Benedetto, S. La cooperazione nel delitto colposo, Milano, 1988, p. 94.; Fiandaca, G. and Musco, E. Diritto penale, parte generale, IV Ed, Bologna 2007, p. 496.
} 
and conscious way, therefore it is the psychological element that characterizes the cooffending referred to Article 113 of the Italian Criminal Code ${ }^{47}$.

However, if we refer to the case-law, we can note that in some cases the Italian Supreme Court has argued that medical-surgical team treatment configures cooffending according to Article 113 of the Italian Criminal Code. In this direction, the Court of Cassation affirmed the responsibility of all members of the medical team for the failure of the operation which resulted in damage to the patient's health, attributable to erroneous basic choices shared by all participants ${ }^{48}$.

In this regard, the Italian Court of Cassation in a case related to the breaking, during a surgical operation of the abdomen, off the edge of the forceps and its sliding into the patient's abdomen, constitute guilty conduct by the doctors, in terms of the failure to count the irons after the wound was sutured. Or, when the Italian Supreme Court notices the medical negligence, under the profile of co-offending according to Article 113 of the Italian Criminal Code of the medical director of a retirement home, who had not checked and supervised that the provisions he had given were observed, by the top position invested ${ }^{49}$.

\section{Conclusions}

In conclusion, it is noted that the greatest perplexities on the issue of medical team criminal liability relate to the principle of reasonable confidence and the risks deriving from it. In this sense, it must be admitted that every professional must be left free to perform his duties and respect the rules of diligence and prudence linked to his specific specialization. In this regard, each member of the medical team entrusts in the fact that his colleagues will respect the medical rules (leges artis), since a doctor part of a team cannot know and evaluate all the previous and/or contextual activities of each of the components in the different areas of specialization. However, on the other hand, such a statement risks entailing the mere disinterest of individual doctors in the work of other colleagues. Therefore, it is necessary to integrate the principle of reasonable confidence with the obligation to supervise or correct the work of the other members of the medical team, where knowledge allows it, especially if it is a matter of gross errors or inexperience's that could compromise the functionality of the entire team.

\footnotetext{
${ }^{47}$ Cass., Sez. VI, 14 maggio 2009, n. 20406.; Cass., Sez. III, 9 gennaio 2009, n. 15707, Abbaneo, Cass. Pen., 2010, p. 626.

${ }^{48}$ Cass. Pen., Sez. IV, 3 novembre 2011, n. 46961, cit.; Cass. Pen., 18 dicembre 2009, n. 3365, dep. 26 gennaio 2010.; Tribunale di Milano, Sez. IX, 16 luglio 2007, 13 ottobre 2007. De Jure e Foro Ambros, 2007, 3, p. 323, and Riv. it. med. leg, 2009, 1, p. 233.; Tribunale di Caltanissetta, 15 gennaio 2003, S e altro. Foro it., 2005, II, p. 621.; Cass. Pen., 4 febbraio 2004, Caffaz e altro.; Trib Massa, 15 dicembre 2000, Caffaz e altro. Riv. pen., 2002, p. 73.; Tribunale di Perugia, 15 gennaio 2002, Casciola e altro. Riv. pen., 2002, p. 394.; Cass. 29 novembre 1988. Cass. pen., 1990, p. 245.; Cass. 13 giugno 1983. Cass. pen., 1984 , p. 1965.

${ }^{49}$ App. Milano, 12 ottobre 1999.; Pret. Genova, 13 novembre 1991. Foro it., 1992, II, 586.; Cfr. Pretura Vibo Valentina, 15 marzo 1999, Garuzzo e altro. Riv. it. med. leg., 2000, p. 875.
} 
The Court of Cassation accurately recalls that the obligation to supervise the work of other colleagues within the team must not be transformed into an unlimited obligation for the doctors. But it is necessary to carry out a careful assessment of the role played by each member and verify the incidence of each person's conduct on the injurious event. Thus, avoiding attributing the criminal liability to the entire medical team, with the risk of falling back into the area of objective liability, in violation of Article 27 of the Italian Constitution.

The medical-surgical treatment carried out by a team presents a multiplicity of problems related to the identification of the criminal liability of the individual components. For this reason, it is important to balance the principle of reasonable confidence and the principle of self-responsibility, to exclude the attribution of the criminal liability $a$ priori for the entire team and at the same time fulfilling the obligation to guarantee the patient's health.

\section{Bibliography}

1. Ambrosetti, F. La responsabilità penale dell'équipe. La responsabilità medica, N. Tedeschini, Wolters Kluwer Italia S.r.l., Milano, 2016, p. 508.

2. Ambrosetti, F., Piccinelli, M., Piccinelli, R. La responsabilità nel lavoro medico d'équipe, Utet, Torino, 2003.

3. Belfiore, E. "Profili penali dell'attività medico - chirurgica in équipe". Arch. pen., 1986, pp. 298-295.

4. Belfiore, E. "Sulla responsabilità colposa nell'ambito dell'attività medico chirurgica in équipe". Foro it., 1983, II-V, p. 167

5. Bettiol, G. "Sul concorso di più persone nei delitti colposi". Scritti giuridici, I, Padova, 1966.

6. Bilancetti, M. and Bilancetti, F. La responsabilità penale e civile del medico, Cedam, Padova, 2013.

7. Blaiotta, R. "Niente resurrezioni, per favore. A proposito di S.U. Mariotti in tema di responsabilità medica". Dir. pen. cont., 28 maggio 2018: https://archiviodpc. dirittopenaleuomo.org/upload/2125-blaiotta2018a.pdf.

8. Brusco, C. "Cassazione e responsabilità penale del medico. Tipicità e determinatezza nel nuovo art. 590 sexies c.p." Dir. pen. cont., 11, 2017, pp. 211219: https://archiviodpc.dirittopenaleuomo.org/upload/6599-brusco1117.pdf.

9. Buzzoni, A. "Responsabilità medica in équipe: gli orientamentigiurisprudenziali", 16 settembre 2006: https://www.altalex.com/documents/news/2006/10/11/ responsabilita-medica-in-equipe-gli-orientamenti-giurisprudenziali. 
10. Caletti, G. M. "Il percorso di depenalizzazione dell'errore medico". Dir. pen. cont., 4, 2019, pp. 7-8: https://dpc-rivista-trimestrale.criminaljusticenetwork. eu/pdf/DPC_Riv_Trim_4_2019_Caletti.pdf.

11. Caletti, G. M. and Matheudakis, M. L. "La Cassazione e il grado della colpa penale del sanitario dopo la riforma "Gelli - Bianco". Dir. proc. pen., 2017, p. 1396.

12. Campana, T. "La correlazione tra inosservanza e/o applicazione delle "linee guida" e responsabilità penale del medico". Cass. pen., 2012, p. 550.

13. Civello, C. "Responsabilità medica e rispetto delle "linee guida" tra colpa grave e colpa lieve (la nuova disposizione del decreto sanità)". Arch. pen., 2013, n. 1.

14. Cognetta, G. "La cooperazione nel delitto colposo". Riv. it. dir. proc. pen., 1980, p. 63.

15. Cupelli, C. "La legge Gelli-Bianco e il primo vaglio della Cassazione: linee guida sì, ma con giudizio". Dir. pen. cont., n. 6, 2018, p. 280.

16. Cupelli, C. "La responsabilita penale degli operatori sanitari e le incerte novità della legge Gelli-Bianco". Cass. Pen., 2017, pp. 1765-1970.

17. De Francesco, G. "Al capezzale della colpa medica". Riv. it. med. leg., 2015, 3, pp. 884-889.

18. Di Benedetto, S. La cooperazione nel delitto colposo, Milano, 1988.

19. Di Giovine, O. "La responsabilità penale del medico: dalle regole ai casi". Riv. it. med. leg., 2013, I, pp. 61-66.

20. Di Landro, A. R. Dalle linee guida e dai protocolli all'individuazione della colpa penale nel settore sanitario, Giappichelli Editore, Torino, 2012, pp. 310-320.

21. Di Pentima, M. G. La responsabilità per l'attività sanitaria in équipe, Giappichelli Editore, Torino, 2009.

22. Fiandaca, G. and Musco, E. Diritto penale, parte generale, IV Ed, Bologna 2007.

23. Fortunato, G. "Ancora sul principio di affidamento e l'équipe medica". Dir. Pen. Cont., 2017, 5, p. 31.

24. Guerriero, C. "Il disegno di legge Gelli cambia i connotati della responsabilità medica", 16 febbraio 2016: www.iurisprudentia.it.

25. Lanza, E. "La responsabilità penale del medico negli orientamenti della dottrina e della giurisprudenza". La responsabilità in ambito sanitario, Aleo S., De Matteis R., Vecchio G., II, Padova, 2014, p. 701.

26. Latagliata, V. voce "Cooperazione nel delitto colposo". Enc. del Dir., Ed X, 1962, p. 615.

27. Malavenda, A. F. "L'équipe medica". La responsabilità medica, N. Tedeschini, Wolters Kluwer Italia S.r.I., Milano, 2016, p. 766. 
28. Mano, Laureta. "Theoretical and practical implementation of the right for an equal enjoyment of health care service." Academicus International Scientific Journal 7.13 (2016): 145-159.

29. Mantovani, F. Diritto penale, Padova, 2007.

30. Mantovani, F. "Il principio di affidamento nel diritto penale". Riv. it. dir. e proc. pen., 02, p. 536.

31. Mantovani, M. "La responsabilità penale nell'attività medico-chirurgica in équipe fra teoria e prassi". Nuova giur. civ. comm., 2010, p. 1169.

32. Mantovani, M. Il principio di affidamento nella teoria del reato colposo, Giuffre Editore, Milano, 1997.

33. Marinucci, G. and Marrubini, G. "Profili penalistici del lavoro medico chirurgicoin équipe". Temi, 1968, p. 217.

34. Mattheudakis, M. L. "La punibilità della colpa penale relazionale del sanitario dopo la riforma "Gelli-Bianco". Dir. pen. cont., 4, 2019, pp. 65-80: https://dpcrivista-trimestrale.criminaljusticenetwork.eu/pdf/DPC_Riv_Trim_4_2019_ Mattheudakis.pdf.;

35. Padovani, T. Codice penale, Milano, 2005.

36. Pagliaro, A. Principi di diritto penale, Milano, 2000.

37. Palazzo, F. "Responsabilità medica, «disagio» professionale e riforme penali". Dir. pen. proc., 2009, 9, pp. 1063-1066.

38. Piras, P. "Il discreto invito della giurisprudenza a fare noi la riforma della colpa medica”. Dir. pen. Cont., 4 luglio 2017: https://archiviodpc.dirittopenaleuomo. org/upload/PIRAS_2017b.pdf.

39. Risicato, L. L'attività medica di equipe tra affidamento ed obblighi di controllo reciproco, Giappichielli Editore, Milano, 2013.

40. Risicato, L. "Omesso controllo sul malgoverno di macchinari capricciosi: non c'è responsabilità penale del dirigente medico". Giur. it., giugno 2016, p. 1490.

41. Roiati, A. Medicina difensiva e colpa professionale medica in diritto penale, Milano, 2012.

42. Romano, B. "La responsabilità penale dell'esercente la professione sanitaria, tra antichi dubbi e nuovi problemi". Dir. pen. cont., 16 novembre 2018: https:// archiviodpc.dirittopenaleuomo.org/upload/8372-romano2018a.pdf.

43. Terrizzi, A. L. "Linee guida e saperi scientifici "interferrenti", la Cassazione continua a non applicare la legge Gelli-Bianco". Dir. pen. cont., 2018, no. 7, p. 104.

44. Vallini, A. "Cooperazione e concause in ipotesi di trattamento sanitario "diacronicamente plurisoggettivo". Dir. pen. proc., 2001, p. 480. 